\title{
'Do you want me to translate this in English or in a better Mandinka language?': Unequal literacy regimes and grassroots spelling practices in peri-urban Gambia
}

\author{
Kasper Juffermans* \\ Department of Culture Studies E' Babylon, Tilburg University, Warandelaan 2, PO Box 90153, 5000 LE Tilburg, Netherlands
}

\section{A R T I C L E I N F O}

\section{Keywords:}

Mandinka

English

Orthography

Literacy

Ideology

Ethnography

Text

\begin{abstract}
A B S T R A C T
This paper presents a comparative ethnographic analysis of two versions of a grassroots text in Mandinka language, one written by a non-formally educated man, the other a respelling by a formally educated urbanite. The analysis points at a crucial difference in spelling practices and inequality in literacy regimes, i.e., between established orthographic English literacy and the more creative, heterographic and emergent local language literacy. It is shown how English orthography affects local ideologies of literacy as well as Mandinka spelling practices itself, in greater or lesser extent, depending on the educational history of the speller.
\end{abstract}

(c) 2011 Elsevier Ltd. All rights reserved.

\section{Introduction}

A major paradox students of language and education in Africa are confronted with is the great diversity and creativity in audible forms of communication and the vast constraints in visible forms of language. For example, the diversity presented in counts of spoken languages (such as Ethnologue's 2009 statement that there are 2110 living languages in Africa) is barely reflected also in literacy practices in the public space or in the education systems. In much of Africa and the postcolonial world more generally, local languages are not primarily taught as subjects or used as languages of literacy instruction in schools beyond the initial grades (cf. Bunyi, 1999; Brock-Utne and Skattum, 2009). This ignoring of local languages in education can be explained as a colonial status quo (de Swaan, 2001), as the result of a deliberate neo-colonial linguistic imperialism (Phillipson, 1992), or simply as a barrier for good pedagogical practice that policy makers need to bridge (Williams, 2006). It can also be explained to have an impact on vernacular language and literacy practices, and on the structure and infrastructure of 'local languaging' itself. ${ }^{1}$

\footnotetext{
* Corresponding author.

E-mail address: k.c.p.juffermans@uvt.nl.

${ }^{1}$ Fieldwork for this paper was undertaken in June-July 2008 and FebruaryMarch 2009 with support from the Department of Language and Culture Studies at Tilburg University. I am indebted to Burama, Almameh, Ansu and Dembo, the Mandinka (re)spellers and translators mentioned in this paper, without whom this paper could never have been written, and to Mark Peters. Versions of this paper were presented at the Literacy Inequalities Conference at the University of East Anglia (September 2009), the American Anthropological Association meeting in Philadelphia (December 2009) and the Point Sud workshop on Language Contact in West Africa in Bamako (February 2010). I am grateful to Jan Blommaert, Caroline Juillard, Sjaak Kroon, Bryan Maddox, Shahrzad Mahootian, Salikoko Mufwene, Dorina Veldhuis and three anonymous reviewers for careful suggestions, criticism and feedback. All remaining shortcomings are my own responsibility.
}

This paper is part of a larger project on language and literacy practices in Africa's smallest country The Gambia (Juffermans, 2010) and deals with Mandinka-English bilingualism and 'periurban' spelling practices. It is meant as a contribution to a sociolinguistics of orthography and spelling (Kress, 2000; Jaffe, 2000, 2009; Sebba, 2000, 2009; Lüpke, 2011) and of literacy at the grassroots level (Fabian, 1990; Blommaert, 2008; Mbodj-Pouye, 2009). Spelling is defined here as the creative representation of sound into writing, and orthography as the normative way of writing right. A useful distinction Kress (2000) makes in this respect is between the 'look' and the 'sound' of spelling, i.e., between the more bottom-up 'transduction of sound into graphic form' and the more top-down 'reproduction of a graphic form (letters as a kind of image) with a graphic form'. 'Grassroots literacy' refers to 'a literacy which works despite an amazingly high degree of indeterminacy and freedom (visible in an erratic orthography, a great disdain for word and sentence boundaries and many other instances of seemingly unmotivated variation)' (Fabian, 2001:65). I will come back to these terms in the final section of this paper.

The single most striking feature of the (visual) linguistic landscape of either urban or rural Gambia is the virtual absence of languages other than English as anything more than proper names or occasional slogans embedded in otherwise monolingual English discourse (Juffermans, 2010). English clearly is the default medium of visual communication in the public space. This observation would lend itself as evidence that Gambian local languages are not written languages, but only spoken 'vernaculars'. And indeed, this is by and large how local languages are treated in the country's educational systems (public and private, secular and Islamic, formal and non-formal) which privilege non-indigenous languages (English and/or Arabic) as media of instruction at all levels of education. Recent mission statements and policy objectives to 
introduce local languages into the formal secular school curriculum notwithstanding (e.g., DoSE, 2004), very little of these policies have been implemented yet (Juffermans and McGlynn, 2009; McGlynn and Martin, 2009; Van Camp and Juffermans, 2010).

Up till now, Gambian local languages are not used for literacy learning in main-stream education, but only in the (non-formal) adult literacy classes that target uneducated, illiterate adults. When it comes to literacy education, children and adults are subjected to two radically different regimes of learning. Children are taught to read and write in English, which is the language of the offices, the modern nation, and the wider world. Adults who have missed this opportunity in their youth are offered an alternative education model consisting of 'adult literacy classes'. 'Adult' here is synonymous with 'local' or 'indigenous'. Children's literacy is not that of adults, but is literacy in the official, international language, English.

In Brandt's (1997) terms, the most powerful 'sponsors of literacy' in The Gambia (i.e., the Department of State for Education, Islamic clergy, various educational stakeholders) are only marginally concerned with literacy acquisition and production in local languages and invest few resources in the systematic teaching of reading and writing in local languages. Literacy in local languages remains more or less marginal, and this is what we see reflected in the public space: a lot of English, occasional Arabic (either in Arabic or in roman script) and only a very small amount of local languages.

Nonetheless, this paper is about literacy production in local languages (Mandinka in particular). For a long time, reading and writing in local languages remained well-hidden for me as a researcher. In my fieldwork, until recently, I got no further than just talk about literacy in local languages (e.g., with adult literacy teachers) but never got to witness people actually practicing literacy in local languages. When I observed people practicing literacy in their private lives, it was always either in English or occasionally in Arabic. It was only in more recent fieldwork that I was introduced to an individual who did practice local language literacy on a regular basis and in whose life local language literacy played (plays) an important role.

The discussion of this paper revolves around this individual and his texts. This person, Burama Janne, will be introduced in section three, after the methodological and theoretical framework of this paper has been outlined. In section four, I will narrate two key incidents I experienced while working with his texts and section five offers a comparative ethnographic analysis of two versions of the same text (a story about a stolen donkey), the original prepared by Burama and the respelling by a higher-educated, Englishliterate person. The paper culminates in a series of remarks on linguistic inequality and Mandinka spelling practices in the presence of English.

The ambition of this paper is to shed light on the actual resources of writing people in a postcolonial, Third World context have access to through formal, non-formal and informal channels of education (Rogers, 2004), and on the implicit hierarchies there are between these channels of education in social life. It is shown how in the absence of a well-established orthography for Gambian local languages, formal education and literacy in English are valued higher than non-formal (adult) education and literacy in the local languages. It is suggested that there are unequal literacy regimes that affect not only how differently educated persons think about language, literacy and education (in terms of what is 'good' and 'bad' language, literacy or education), but also how differently educated persons practice literacy on the grassroots level.

\section{An ethnography of text}

Ethnography is a method-cum-theory of inquiry into social reality that takes complexity as its starting point and aims at a comprehensive, holistic and critical description of big social processes in the world on the basis of small events. Hymes' (1967) ethnography as speaking is an important precursor for the sort of language-centred ethnography practiced here (see also Basso, 1974; Szwed, 1981; Fabian, 2001; Baynham, 2004; Blommaert, 2008). The significance of the ethnography of speaking lies in particular in the fact that it avoids the term 'language' in its theoretical apparatus, which allows the ethnographic linguist to move its focus from 'languages', 'cultures', or 'tribes' to communicative events (or literacy events) that are not necessarily locked up in particular languages or cultures and to communities of practice in which more than one medium and mode of communication can be used at the same time (Rampton, 2000; Jørgensen, 2008).

Lillis (2008) makes a distinction between three possible approaches to ethnography, as method, methodology, and as 'deep theorising'. She illustrates these three senses of ethnography with her own research on academic writing, but the distinction is a useful theorisation for ethnographic epistemologies in general. She describes that some authors use the word ethnography as soon as their method involves talking with people about what they do. In literacy studies, 'talk about texts' may be enough for an ethnographic project only in the first sense of the word. Ethnography is then used in its thinnest version, as method. I attempt to apply ethnography in this study also in the second and third meanings of the term, methodologically as well as theoretically.

Ethnography as methodology involves at least three elements, 'thick description', 'thick participation' and 'deep hanging out'. 'Thick description', a term introduced by Geertz (1973), refers to a particular thorough way of describing cultural behaviour in a broadly contextualised way, such that the behaviour becomes meaningful and understandable to outsiders. 'Thick participation' is a term introduced by Sarangi (2007:573) to call attention to the degree of socialization that is needed in ethnographic work 'in order to achieve a threshold for interpretive understanding'. Although in part already covered by 'thick participation', I would like to put forward a third element that is necessary for ethnographic projects, 'deep hanging out'. 'Deep hanging out' is a term used by Geertz (1998) in an essay for The New York Review of Books in which he compares two ethnographic monographs, one by a celebrated scholar in the relatively new field of cultural studies (Clifford, 1997); the other by an old-fashioned and relatively unknown French anthropologist (Clastres, 1998 [1972]). Geertz accuses Clifford as proponent of postmodern, multi-sited ethnography of 'non-immersive hit-and-run ethnography', 'drifting, freestyle anthropology' and commends Clastres as proponent of an antiquated anthropology for his thorough commitment to 'localized, long-term, close-in, vernacular field research - what Clifford at one point lightly calls deep hanging out' (Geertz, 1998; see also Wogan, 2004). 'Deep hanging out' is turned positive by Geertz and proposed as ethnographic requirement for cultural understanding and interpretative adequacy.

For ethnography as theory, we need to assume an ethnographic view of the world. Such an ethnographic view of the world assumes that social reality and language practices are inherently complex and are most adequately described using the holistic descriptive 'method' of ethnographic fieldwork as developed in the early twentieth century by the anthropologists Boas and Malinowski, and methodically applied to the study of language by Hymes (1967) in his ethnography of speaking model. When ethnography is seen as theory rather than method, it becomes possible to separate ethnography from simply 'doing fieldwork'. Obviously, a lot of work in the field is non-ethnographic, and there is even ethnographic work without fieldwork. Blommaert's book Grassroots Literacy (2008) for instance, is ethnography without traditional fieldwork in the form of a stay in the field. 
The research reported here is based on classic ethnographic fieldwork or 'deep hanging out' in different locations and sections of Gambian society, ${ }^{2}$ but it also subscribes to the possibility of an 'ethnography of text' - the idea that an ethnographic project can be built around the analysis of a series of texts, even in the absence of observed literacy events (cf. Juffermans, 2009). To understand the potential of ethnographies of text, we need to distinguish between 'literacy events', 'literacy practices' and 'literacy products'. As Street (2000:21f) explains, literacy practices are the more robust, broader, structural forms of individual literacy events. A literacy event refers to 'a particular situation where things [that involve reading and/or writing] are happening and you can see them happening'. Literacy practices on the other hand, 'refer to this broader cultural conception of particular ways of thinking about and doing reading and writing in cultural contexts'. Literacy events and literacy practices thus relate to each other in a somewhat comparable way as utterances and grammar do. Literacy events are the empirically observable situations that allow literacy researchers to make statements about literacy as situated in particular contexts.

Individual literacy events usually leave more or less durable traces, i.e., literacy products. In an ethnography of text, we study these traces or products as a window into literacy practices. The products people leave behind offer additional, more tangible evidence of what people are doing when they engage in literacy events or practice literacy. The texts people write may reveal more about how they practice literacy than they would be able to answer on questions regarding their literacy practices. Mbodj-Pouye (2008) in her study of village literacies in Mali remarks that texts found in circulation in a particular community can be of the same use to ethnographers as historical documents and archival records are to historians. Mundane, everyday literacy products can serve to extrapolate, (re)construct and theorise on lived social, cultural, historical or linguistic realities.

In this paper I study one individual's texts and the reactions to one of these texts by persons in his environment as a window into understanding the broader social ecology of education and literacy learning in a postcolonial and Third World country that is The Gambia.

\section{Burama's texts on paper and on the wall}

I first met with Burama Janne (his real name) in July 2008. My visit to him was arranged by his younger brother Almameh with whom I moved about much in the course of my fieldwork. Burama, I was told, kept notes and stories in Mandinka and wrote the names and phone numbers of their relatives in 'funny' spellings on the walls of his house. His own name as used here, Burama instead of 'Ebrima' or 'Ibrahima', and Janne instead of 'Janneh', is exemplary of this. Almameh had also informed Burama about my interest in his local language writing. On my first visit, little time was wasted with exchanging courtesies before I was presented a series of texts on paper as well as on the walls of his house.

On paper, Burama presented nine loosely kept texts, two of which were written especially for me, including one in my presence. Six of these texts were professional reports dated between '7/4/1991' and '7/10/1995' of business trips to various places within and outside The Gambia (Basse, Jara Soma, Bissau,

\footnotetext{
2 This paper fits in a larger research project on literacy and multilingualism in Gambian society for which an aggregate twelve months of fieldwork has been carried out between 2004 and 2009. The fieldwork comprised research in both urban and rural locations on linguistic landscapes, language in education and personal literacy practices, and included a combination of ethnographic and discourse analytical (or philological) research methods (see Juffermans, 2010 for details).
}

Casamance), documenting in considerable detail of the quantities and prices of purchased cow skins, repayment instalments of outstanding debts, as well as miscellaneous fees and duties that had to be paid. Burama explained that he owed his job as a travelling hide merchant primarily to his ability to keep records of these transactions in writing. The first text shown and explained to me was a short autobiographical note on paper that is represented in transcription and translation in Fragment 1 below.

The first paragraph states Burama's personal details as well as those of two of his relatives that I knew. The second paragraph anticipates my interests in his local language writing and outlines his learning history with regard to literacy. It begins and concludes with the statement that he is 'pleased', either with his competence in Mandinka writing, and/or with my interest in this. The third paragraph explains something of Burama's social and economic status with reference to the old well in the corner of his compound. In the talk surrounding the text, he explained that he settled on this land coming from a more eastern and rural part of the country in a time when few people had settled here. He explained that he built one of first wells in the area and that people came from far to fetch water in his compound, which clearly made him proud. This is followed, however, by the remark that the well is broken now, and that 'his people' (i.e., his family members) now have to go out to fetch water, which is indicative of their current situation of material hardship. The short text repetitively concludes with Burama's address and phone number as a sort of signature.

Apart from the texts on paper, Burama had also written a series of short notes with charcoal on the white-painted walls of his house. These notes, three of which are reproduced below (see Fragments 2, 3 and 4), elaborate on the autobiographical note on paper. They give particulars of the construction of his house (such as the exact date when it was built, line 23), as well as of his means of livelihood and the composition of his family (lines 29-30). These notes were written especially for me as they were meant to illustrate his writing in Mandinka (see Fig. 1 for the two of us in action). It should be noted that these texts are not naturalistic data in the sense of texts that existed prior to and independent of this research, but that they instead emerged in the interactive context of ethnographic data collection.

In the final of the three notes reproduced below, Burama points to the important divide in Gambian society between Kombo (the west, the urban areas) and the rest of the country (the provinces, the rural areas). Moving westwards implies moving up on the scale from rural to urban, which is at the same time also a social and linguistic scale (Blommaert, 2007). Socio-economically, urban dwellers have different access to educational and professional markets compared to those who reside in the rural areas. Sociolinguistically, moving westwards often also implies moving away from areas where Mandinka is a lingua franca to areas where Wolof is the dominant language (e.g., in Serrekunda, Banjul). In Burama's case, this trajectory is a moderate one as he does not move from the 'far east' to the 'far west', but only from Foni to one the first settlements west of Brikama. His move is also socioeconomically and socio-linguistically moderate (yet significant enough), as the place of his new settlement is not entirely urban yet and the dominant language here is still Mandinka. To describe this intermediate zone, we may borrow a term from geography, and characterise Burama's town as a peri-urban place. In geography the term peri-urban stands for the rural (agricultural) wasteland in the margins of the urban centres. People living in the peri-urban areas help sustain the city (through their labour) and also reap its benefits (through work, education, manufactured and traded goods). The term carries in it the assumption that urban and rural are not absolute categories, but categories of degree, of more or less. 
Fragment 1

Burama's self-introduction (on paper).

\begin{tabular}{|c|c|c|}
\hline & Transcription & Translation \\
\hline 1 & $\begin{array}{l}\text { NTe TOOMu } \\
\text { BuRAMA JAnne } \\
\text { Le Ti }\end{array}$ & $\begin{array}{l}\text { My name is } \\
\text { Burama Janne. }\end{array}$ \\
\hline 5 & $\begin{array}{l}\text { FARATO Tel_\#\#\#\#\#\#\# } \\
\text { BURAMA JA nneH } \\
\text { NdOOMA KARAMO JAnne TL \#\#\#\#\#\#\# } \\
\text { ALIMAMU JA nne NdOOMA \#\#\#\#\#\#\# }\end{array}$ & $\begin{array}{l}\text { Farato, Tel.: \# } \\
\text { Burama Janneh } \\
\text { My younger brother Karamo Janneh. Tel.\# } \\
\text { Almameh Janneh my younger brother. \# }\end{array}$ \\
\hline 10 & $\begin{array}{l}\text { KonTAAniTA NMAn Ta KARAn bungoTo } \\
\text { Fo NGA LETARo SAF e MAndinKA - } \\
\text { KAngOLA KAATo. NTe Mu MAndinKo LeTi } \\
\text { WoTo NFAn Si sarono, wo LALu WoTo } \\
\text { KonTAniTA BAKe BAKe }\end{array}$ & $\begin{array}{l}\text { I am pleased. I did not go to school. } \\
\text { But I can write letters in Mandinka } \\
\text { language. I am a Mandinka. } \\
\text { Therefore I can be my own tutor in this. } \\
\text { I am very very pleased. }\end{array}$ \\
\hline 20 & $\begin{array}{l}\text { MNA nyin KoLongo sing 4/6/1995 } \\
\text { woTo Mo Moolumenubu Jan MAAFAngla } \\
\text { Ebe KAnaa Giibiyoola NNa suwo leKoNo } \\
\text { BARi kolongo Tinyaa TAle sanyi } \\
\text { nna Moolu KATA Mola Le la } \\
\text { KonongoLe To nyinKoLon ye. } \\
\text { MnaFaa BAKe BAKe Te } \text { no Menna }_{\text {aye Giyoo SoTo }}\end{array}$ & $\begin{array}{l}\text { I dug this well on 4/6/1995. } \\
\text { Then many people in this surrounding } \\
\text { came to fetch water in my compound. } \\
\text { But the well is broken now. } \\
\text { My people now go to other people's } \\
\text { well. This well } \\
\text { was very very important in that time } \\
\text { to have water. }\end{array}$ \\
\hline & AdeReci BuRAMA JA nne FARATO F \#\#\#\#\#\#\# & Address: Burama Janneh, Farato, Tel.\#. \\
\hline
\end{tabular}

Fragment 2

Note on the wall (about his house).

\section{Transcription}

22 Be Mna nyin bungo loota 4/3/1993 molo le J оо KA Bu $\mathrm{R}_{\mathrm{i}}$ loo Kоo Kosi Nyaa Modo Jao KAn Bungo loo

25 FO APAR ETA ASA WONTA nang

\section{Translation}

My this house was built on 4/3/1993. I paid people to lay blocks and I paid others to erect the house up to its completion now.

Fragment 3

Note on the wall (about his literacy and his family).

\begin{tabular}{lll}
\hline Transcription & Translation \\
\hline 26 & $\begin{array}{l}\text { AdunMna nyinKeeba karango } \\
\text { Nyi mnaFele KATu ndingolo nKeela- }\end{array}$ & $\begin{array}{l}\text { And my this adult education/literacy } \\
\text { has benefit to me because I pay } \\
\text { KAnbango Joo Nyin Kango LelA }\end{array}$ \\
$\begin{array}{l}\text { Nga musu FulA le SoTo } \\
\text { Din Kononto le Soto }\end{array}$ & $\begin{array}{l}\text { I have two wives } \\
\text { [and] have nine children. }\end{array}$ \\
WOTO nyin KARAngo ye & Then this education/literacy \\
MnaFea BAKe BAKe & is of great great benefit to me.
\end{tabular}

Fragment 4

Note on the wall (about his migration).

\begin{tabular}{ll}
\hline Transcription & Translation \\
\hline Nyin FAnaa Mu KeKende & This is also great goodness: \\
yAA bAAleTi ka koridaa soTo. & to have a compound, \\
35 & in Kombo here, if you come from \\
Bombo JAng niiE botA & outside. If they hear [you] say \\
Koridaa SOTO KOMbA JAng & you have a compound in Kombo here, \\
ELA MoolomenubeBAnTA La & your people who are outside \\
Eka,kontAn BAKe BAKe & [will be] very very happy.
\end{tabular}



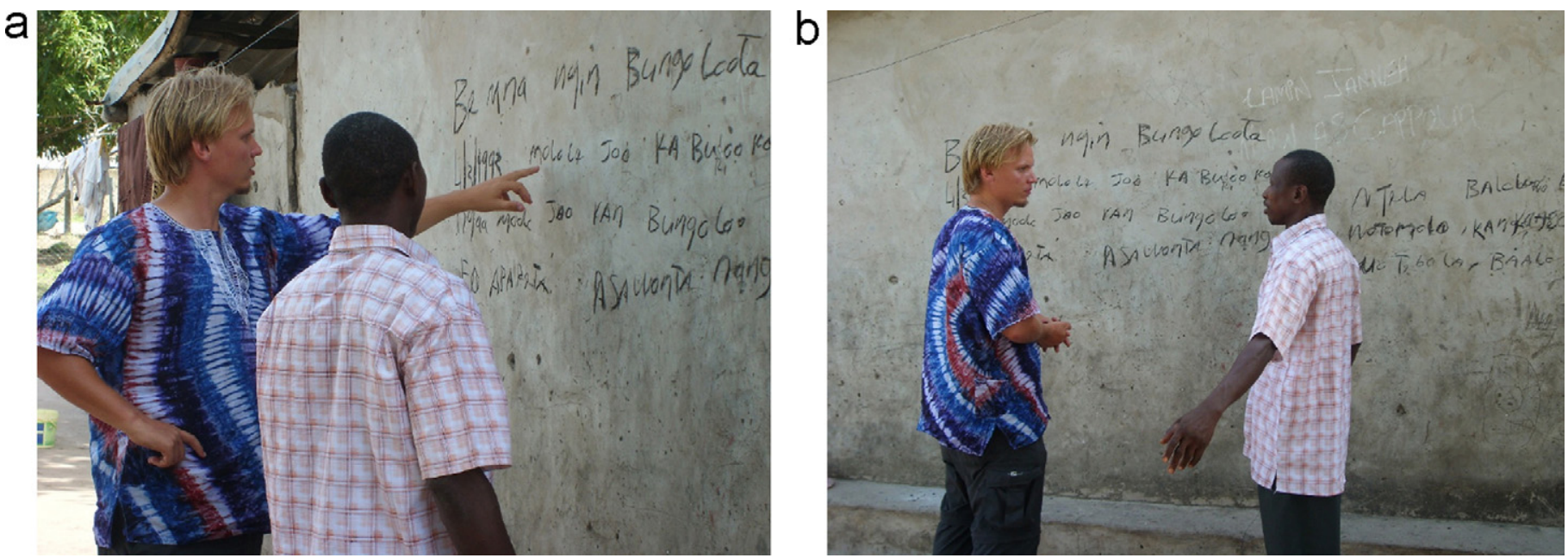

Fig. 1. (a) and (b) Interpreting the inscriptions on the wall (photo courtesy Almameh Janneh).

The fragments discussed so far are meant to give a flavour of the sort of person that Burama is and the literacies he is engaged in. In the following paragraph I will offer an ethnographic comparative analysis of two versions of a short story in Mandinka, the original written by Burama, and a respelling.

\section{The donkey story, in 'good' and in 'bad' Mandinka}

One of the nine texts on paper Burama gave me is a story narrated in the first person, of a dispute over the ownership of a donkey. This text, that I shall call the donkey story, is reproduced in Fig. 2(a) and transcribed in Fragment 5(a). I photographed and prepared electronic transcriptions of the texts in the field, but the translation and annotation of the documents was something I worked on at home in interaction with Gambian 'informants' (friends) over the Internet.

Here I would like to narrate two 'key incidents' (Kroon and Sturm, 2000) that occurred in the process of translating and working with the texts, in particular the donkey story. Both incidents are 'key' because they reveal important formal and social characteristics of the texts and point at very fundamental linguistic inequalities in the ecology of education and literacy in Gambian society. These incidents are key to understanding why 'small languages' are not equal to world languages, in ways that go beyond notions of linguistic imperialism and language rights (see the discussion between Blommaert, 2001 and Skutnabb-Kangas et al., 2001). By narrating these two events, I aim to demonstrate that there is a structural inequality within small languages that is inherent in the infrastructure of the language, and that this is an inequality that is not easily resolved by agendas of empowerment that target learners only.

The first incident occurred in the field in July 2008. I gave the first page of the text to my friend Ansu, who is a well-educated young professional and 'family man' living in Greater Serrekunda. I gave him the piece of paper (an enlarged black-andwhite print-out of the digital photograph) with the request to help me translate this text, which he accepted. He then passed the page on to a third, mutual friend of ours - Dembo, a similarly educated urbanite a couple of years older than both of us. Dembo returned the photographed text to me in Ansu's house a few days later together with a respelling of that original version instead of a translation. The respelling as reproduced in Fig. 2(b) and transcribed in Fragment 5(b) was accompanied with the comment that this was the 'correct writing' and that 'the first writing [i.e., Burama's version] ha[d] some mistakes', and is how you write 'if you don't know the language very well'. Translation of the text, or rather a paraphrase, was only given to me orally.

The second incident is a reply e-mail I received from Burama's younger brother Almameh. Almameh, or Alex, is the person that is perhaps most central in my network, and is also the person I am most in touch with over e-mail (or occasionally over telephone) when I am not in The Gambia. I often ask his opinion or consult him to get certain facts right for the pieces I write. He also feeds me with information of the most important events in the lives of the people we both know (marriages, births, deaths, travelling, etc.). In the course of our regular e-mail conversations, I asked him on 23rd April 2009 at 15:20 from my office in Tilburg 'for another favour' and made a semi-serious joke that 'I should almost start paying [him] for [his] help'. I explained that I was 'working on the texts [his] brother Burama ha[d] given me last year.' I asked him if he could 'please help me translate the text below one line after the other.' His reply at 02:36 [00:36 Gambian Time] while on night duty at work with free internet access rebuked my semi-joke suggesting that my request was formulated too polite ('cuz dont asked me to give you a favour pls just tell Alex do this for me') and that 'payment' is inappropriate among friends and kins ('cuz we cannot pay for each other, how much do you think you can pay me? we ar now Baading [relatives, lit. father's children]'). This was, however, followed by a suggestive request for assistance (but not as payment for any services), and an explanation of his hardship at the time related to an involuntary professional posting to the far east of the country. The e-mail ended with an appeal to clarify my translation request: 'Do you want me to translitre this mandinka texts in English for you or in a better mandinka language?'. I replied to him that I just needed it in English, which I got from him at 12:53 [10:53 G.T.], less than $24 \mathrm{~h}$ after my initial request.

The two incidents - the first where my request for translation was not met with a proper translation but with a respelling, and the second where I received an explicit request for clarification if I meant a proper translation or a respelling - served as 'rich points' (Agar, 1995) in my understanding of linguistic inequality and spelling practices in The Gambia. According to my translators, the original text was not written in the 'best' or most 'correct' of all conceivable forms of Mandinka. And if I requested for help with understanding the text, what I most likely needed help with, was with transforming the text in another, 'better' form of Mandinka. 
a

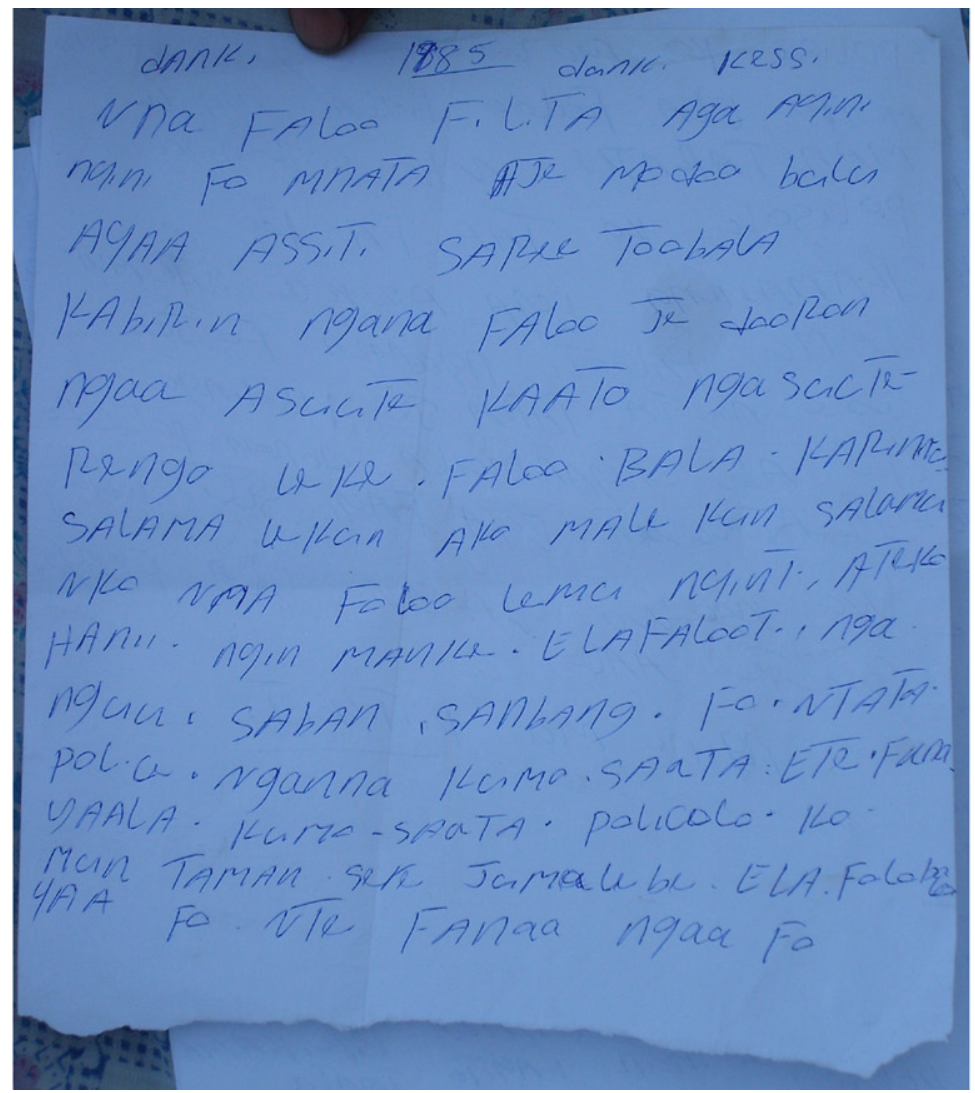

b

A ACADEMY Middle East \& Africa

NaA - Faloo feelee Tha

FOR - NAAA NJAA NYENE FOR

NATIA A JEH MODOU BULUU

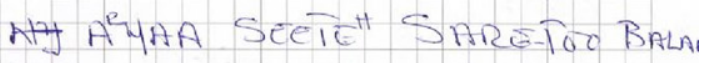

kabering nigana frlloo TeH

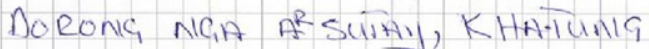

NCIA SUTHA-RHACIO LEKEHT FHLOO-BNL

KARIM-KoO-SALAMU-ALAY-Kum.

NKO - MMLAY-KUM-SMLAM.

NKO-NHA FALOO-LEMUA NIYINC, - REE

ADE LEHKOO H WNEE NYING, MATNG, KOM

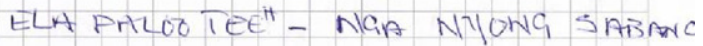

saabang for nitaía polico.

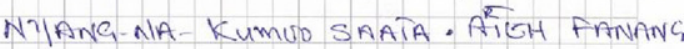

varala Kumoo sarnia. polico ko municía.

manla-scer Jumar Leta-Boh ela anloo ball

AIAA-FOO- NIEH FANANIG NGAA FOO.

Fig. 2. (a) Burama's original. (b) Dembo's respelling.

Fragment 5

The donkey story in two spellings and translation.

\section{(a) Transcript of Burama's original}

(b)Transcript of Dembo's respelling

\section{0 dAnK1 1985 danK1 Kess I}

Nna FAloo FılाזA Aga Ayını nYInIFo MnATA AJ E MOdoo bulu AYAA ASS IT1 SAR Ee TOObAlA KAbIRın ngana FAloo Je dooron

45 ngaa AsuuteKAATO nga suureRengo le ке. FAloo . BAlA . KARInne SAlAMA le Kun AKO MAle Kun SAlamu NKo Nna foloo leмu nyınTı, Атеко HAnı1. nYInMAnKe . E lA FAlooT1. nga

50 nyuu, SA bAn, SAnbAng. FO NTATA Police . Nganna KuMO . SAaTA . Ete.fana YAAlA KUMO-SAatA . Polıcolo. KO MUn TAMAn sere Juma le be .ElA Falo ba la YAA FO NTe FAnaa ngaa Fo

55 Polıso Kо MO WO MO Eуе TAMAn SERo MenTo ELA Faloo BALA nIn-WoMAn TARAJ ee NBe SOROnna polisoluKo TAA FA loo KAMAneng ЕУA AKOroce NTe Men-

60 TA Mu FAloot1 ngamen Fo Jee wole naaTa TARA J e. keedingo ko abe diyAamula doron policolu YA ATUle bUNEYA FAY 1 seli, WOTOWo mowo EnyAn Ela Fengo

suute laAle
NAA - FALOO FEE LEE TAH FOR - NAA NYAA NYENE FOR N NATA $A^{R}$ JEH MODOU BULUU AY A ${ }^{R}$ YAA SEETE ${ }^{H}$ SARE -TOO BALAA KABERING NGANA FALOO JEH DORONG NGA A ${ }^{R}$ SUTAY, KHA.TUNG NGA SUTAY RANGO LEKEH FALOO -BALA. KARIM. KOO-SALAMU-ALAY-KUMNKO - MALAY-KUM-SALAM. NKO - NA ${ }^{R}$ FALOO -LEMU NYING-TEE ${ }^{H} A^{R}$-THE-KOO HANEE NYING MANG-KEH ELA FALOO TEE ${ }^{\mathrm{H}}$ - NGA NYONG SABANG -SAABANG FOR AR NAT NTATA POLICO . NYANG-NA- KUMOO SAATA. A TEH FANANG YAALA KUMOO SANTA. POLICO KO

MUNG-TAA MANG-SERR JUMAA LEH -BEH ELA FALOO BALA AYAA-FOO -. NTEH FANANG NGAA FOO .

(only first page given to Dembo)
(c)Translation (based on both spellings)

Donkey 1985 Donkey Problem

My donkey got lost. I searched and searched for it. I found it on Modou's hand. He tied it on a [donkey] cart. When I saw my donkey, always I recognised it, because I put a mark on the donkey. Then [I said] salaam-maleikum, he said maleikum-salaam. I said this here is my donkey. He said no, this is not your donkey. We argued and argued until we went to the police. I told my story. He too told his story. The police asked: what mark, where is it on your donkey? He said [his] and I also said [mine].

The police asked both of us, your mark, where is it on your donkey? If it does not match, I will lock you up. The police said, go bring the donkey and let me observe that where on the donkey I was described to see [the mark], is indeed what we see on it. The man wanted to talk immediately. The police slapped him and put him in the cell. Therefore, everybody must recognize his property. 
Dembo's claim that his spelling is a more 'correct' way of writing Mandinka than Burama's, is a peculiar language ideological appreciation of his own and Burama's writing that is based more on social than on textual analysis. Dembo's value judgement of the original is not based on linguistic, but on sociolinguistic analysis, on the recognition of Burama as a non-formally educated writer. In spite of Dembo's disqualification of Burama's writing, however, Burama's spelling remains relatively close to the 'official' spelling employed and prescribed in language materials prepared by the Gambian government and international (Christian) NGOS concerned with (adult) literacy development in Mandinka (Faye and Sillah, 1956; Sidibe, 1979; WEC International, 2010 [undated]). If these standards are anything to go by, Burama's spelling is indeed 'more correct' than Dembo's. But the point here is that these standards are not commonly 'enregistered' (i.e., socially recognised and practically accepted as norm, Agha, 2005; see also Dong, 2010), and thus not known to most people, especially not to formally, English-only educated persons. Mandinka has an 'official' spelling only in the sense that it is established by the colonial and postcolonial governments and by NGOS, but the fact that it is not commonly known or recognised as norm makes it official or standard only in theory, not in practice. Spelling Mandinka remains, for a large part, a creative and heterographic affair.

Fig. 2(a) shows a reproduction of Burama's original spelling of the donkey story and Fig. 2(b) shows Dembo's respelling. Fragment 5(a) is a transcription of the original in Fig. 2(a) and Fragment 5(b) corresponds with the respelling in Fig. 2(b). The translation in Fragment 5(c) is based on the various translations I received (first orally by Burama and Dembo, later in writing over e-mail by Almameh and Dembo) and complemented with my own comparative textual analysis and interpretation.

\section{A linguistic comparison}

In comparing the two spelling systems as produced by Burama and Dembo, there are a number of general remarks to be made. First, there are only nine words that are spelled the same in these texts: faloo (twice), ngana, nko, ntata, saata, yaala, ela, ngaa. Second, we also notice a striking difference in capitalisation. Burama's version uses lower and upper case letters in an unsystematic, somewhat miscellaneous way (e.g., Nna FAloo FilitA) while Dembo's text is entirely in capital letters (e.g., NAA - FALOO FEE LEE TAH.$^{3}$ Also, in Burama's spelling there is a rather sparse use of punctuation marking, whereas Dembo punctuates rather abundantly, with dashes on the word-level and dots and commas on the sentence level. Fourth, an innovative feature that is unique for Dembo's spelling is the use of superscript as spelling device. This happens for the double (geminated) $\mathrm{n}$ in $n^{n}$ ata, the aspirated word-final vowels in seete $e^{h}$ and tee $e^{h}$ (twice) and the lengthened / a:/ vowel in $a^{r} j e h, a^{r} y a a, a^{r}$ sutay, $n a^{r}$ and $a^{r}$-teh-koo. Finally, we also notice that the word boundaries are organised differently in each version. Excluding the title, and treating hyphens as word separators, the first page of Burama's text has 83 words compared with 93 words (not including the five words that are struck through) in Dembo's version. Compare the following sentences meaning 'he said no, this is not your donkey': ateko hanı. nyın manke. e la falootı (seven words, Burama's version) and $a^{r}$-the-koo hanee nying mang-keh ela faloo tee ${ }^{h}$ (ten words, Dembo's version).

According to the Mandinka language materials prepared by the American Peace Corps (Colley, 1995b, 1995a) and the missionaries of WEC International (Lück and Henderson, 1993; WEC Interna-

\footnotetext{
${ }^{3}$ In what follows, abstraction is made of the original capitalisation and words are represented in lower casing.
}

tional, 2002, 2010 [undated]), all consonants of the English alphabet are used in the Mandinka alphabet except $\langle\mathrm{Z}\rangle,\langle\mathrm{x}\rangle,\langle\mathrm{V}\rangle$, $\langle\mathrm{q}\rangle$ and $\langle\mathrm{g}\rangle$ and there are two special characters that do not occur in English, namely $\langle\mathrm{y}\rangle$ for the velar nasal $/ \mathrm{n} /$ and $\langle\tilde{\mathrm{n}}\rangle$ with a tilde for the palatal nasal $/ \mathrm{n} /$. These two graphemes are proposed in order to adhere to a the 'phonemic principle' which supposes that a one phoneme-one grapheme relation is ideal (see Lüpke, 2011). Burama and Dembo however, depart from this principle and use other, double graphemes to represent these nasal consonants. Although their spelling systems differ in many respects, they agree on representing $/ \mathrm{y} /$ with $\langle\mathrm{ng}\rangle$ (e.g., ngana, suute-rengo vs. ngana, sutay-rango) and $/ \mathrm{n} /$ with $\langle$ ny $\rangle$ (nyini, nyinti, nyin vs. nyene, nying tee ${ }^{h}$, nying). In word-final position, Burama also uses $\langle\mathrm{n}\rangle$ for $/ \mathrm{y} /$ (e.g., kabirin, dooron, nyin manke).

The letter $\langle c\rangle$ is prescribed in the language materials as representing the $/ \mathrm{t} \mathrm{s} /$ sound as in the verb kacaa 'to chat', but in both Burama's and Dembo's spelling systems, $\langle c\rangle$ is also used to represent /s/ (police, policolu, akoroce vs. polico). In Burama's spelling we also find the loanword police with an $\langle\mathrm{S}\rangle$ (poliso, polisolu). In Dembo's spelling it is constantly written with $\langle c\rangle$. In Dembo's spelling we also find examples of post-aspirated consonants: 〈kh〉 (kha.tung) and 〈th〉 $\left(a^{r}\right.$-the-koo). Table 1 gives more details and examples.

The vowels in Burama's and Dembo's spelling systems present an even more interesting point of comparison as the diversity of sound-letter correspondences and the divergence of the phonemic principle is greater here. The $/ \mathrm{i} /$ sound for instance is represented in three different ways in Burama's spelling and in even four different ways in Dembo's spelling. Phonologically only two different types of /i/ can be distinguished, the lengthened close front unrounded vowel /i:/ and the near-close near-front unrounded vowel $/ 1 /$. The long /i:/ is represented by 〈i ( filita, nyini, kabirin), 〈ii ( hanii) and $\langle\mathrm{e}\rangle$ (e la, ete) in Burama's system and by $\langle$ ee $\rangle$ (fee lee ta), $\left\langle\mathrm{ee}^{\mathrm{h}}\right\rangle\left(\right.$ tee $\left.^{h}\right)$ and (e) (e la, nyene, kabering) in Dembo's system. The short, more centralised $/ 1 /$ is represented in both systems with $\langle i\rangle$ (kabirin, nyin vs. kabering, nying).

The /e/ sound, which is either realised as lengthened close-mid front unrounded vowel (/e/) or as short open-mid front unrounded vowel $(/ \varepsilon /)$ in the phonology of Mandinka, has three realisations in each spelling system. The long /e:/ is represented by $\langle\mathrm{e}\rangle$ (suute, nte,

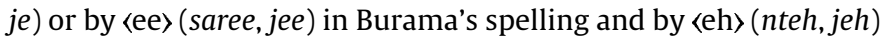
or 〈ay〉 (sutay) in Dembo's spelling. The short $/ \varepsilon /$ is represented in Burama's system with 〈e〉 (suute-rengo) and in Dembo's system with 〈a〉 (sutay-rango).

The open front unrounded vowel /a/ which may have either long (/a:/) or short (/a/) vowel quality is represented in two ways in Burama's spelling and in as many as four different ways in Dembo's spelling system. Burama uses 〈a〉 for the unlengthened variant (faloo, filita, bala) and 〈aa) for the lengthened variant (ayaa, ngaa). Dembo also uses 〈aa) for the lengthened /a:/ sound ( $a^{r} y a a, n a a$, jumaa), but three different graphemes for the short $/ \mathrm{a} /:\langle\mathrm{a}\rangle$ (faloo), $\langle\mathrm{ah}\rangle$ (fee lee tah) and $\left\langle\mathrm{a}^{\mathrm{r}}\right\rangle\left(a^{r} j e h, a^{r}\right.$ sutay).

The close back rounded vowel $/ \mathrm{u} /$ and the mid back rounded vowel /o/ present less variety in both spelling systems. Both Burama and Dembo use $\langle 0\rangle$ and $\langle\mathrm{u}\rangle$ for the short variants $/ \mathrm{\rho} /$ and / $\mathrm{v} / \mathrm{and}\langle\mathrm{Oo}\rangle$ and $\langle\mathrm{uu}\rangle$ for the lengthened variants /o:/ and /u:/. However, they do not always agree on whether a vowel in a word should be a long or short one (e.g., compare dooron and bulu in Burama's spelling with dorong and buluu in Dembo's spelling).

Table 1 summarises the linguistic comparison of Burama's and Dembo's spelling systems in a more systematic and detailed way and gives additional contrastive examples. In the next section, this comparison is interpreted sociolinguistically.

Changes in meaning as a result of the respelling are noticed in only one or two occasions. The most striking difference in 
meaning is the misinterpretation of karinne in line 46 as a person's name with a verb form (Karim koo 'Karim says') instead of a spelling of kabiring 'when, since' with the second syllable -biomitted. Subsequently in line 47 , the verbal form ako 'he says' is changed into $n k o$ 'I say' to cover up for the previous misunderstanding of ka-bi-rinne. Thus, the respelling reads karinne salama le kun, ako male kun salamu 'then [I said] salaam-aleikum, he said maleikum-salaam', whereas the original reads karim koo salamualay-kum, nko malay-kum-salam 'Karim said salaam-aleikum, I said maleikum-salaam'. On the other hand, certain ambiguities in Burama's spelling are also clarified in Dembo's spelling. The visual image of the word nguu or nyuu in the sequence nga nguu/nyuu saban sanbang in line 50 suggests that the second letter of this word is a $\langle\mathrm{g}\rangle$, which does not lead to a dictionary entry. This is easily detected by Dembo as an awkward spelling of $\langle\mathrm{y}\rangle$ and respelled as nga nyong sabang saabang, which is recoverable in the dictionary (Colley, 1995a) as ñoo saba meaning 'to fight, pull, compete, argue'.

\section{Spelling Mandinka in the presence of English}

The most striking difference perhaps between Burama's and Dembo's spelling is the difference in degree of English orthographic influence on their spelling systems. Both Burama and Dembo spell in relative 'freedom' (Fabian, 1992), not being hindered by strictly regimented rules governing how they should spell. Even though orthographies for Mandinka and other local languages have been developed, their use is not promoted or

Table 1

A comparison of Burama's and Dembo's spelling systems in the donkey story.

\section{Burama's original version Dembo's respelling}

\section{General characteristics}

(1) only nine words in same spelling: faloo (2x), ngana, nko, ntata, saata, yaala, ela, ngaa

(2) miscellaneous use of lower and upper entire text in capital letters: NAA - FALOO FEE LEE TAH

case letters: Nna FAloo FIlITA

(3) sparse use of punctuation symbols:

$\langle\rangle.\langle\rangle,\langle-\rangle$

abundant use of punctuation, at word-level:

(4)

$\langle-\rangle\langle\langle-\rangle$, at sentence-level: $\langle\rangle.\langle\rangle$,

superscript as spelling device

$-n^{n}$ ata, tee ${ }^{h}, a^{r}$ teh

(5) word boundaries are organised differently:

p.1: 83 words (excl. title);

one page only: 93 words (+5 struck through)

p.2: 63 words

-nna faloo filita (3)

-ayaa assitı saree toobala (4)

-nko nna foloo le mu nyıntı (6)

-ateko hanı. nyın manke. e la falootı (7)

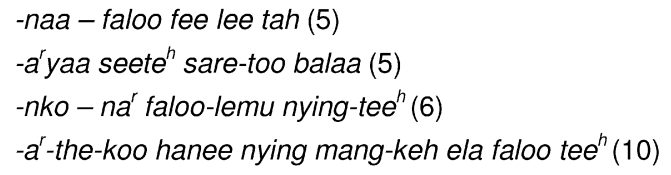

\section{Representation of consonants}

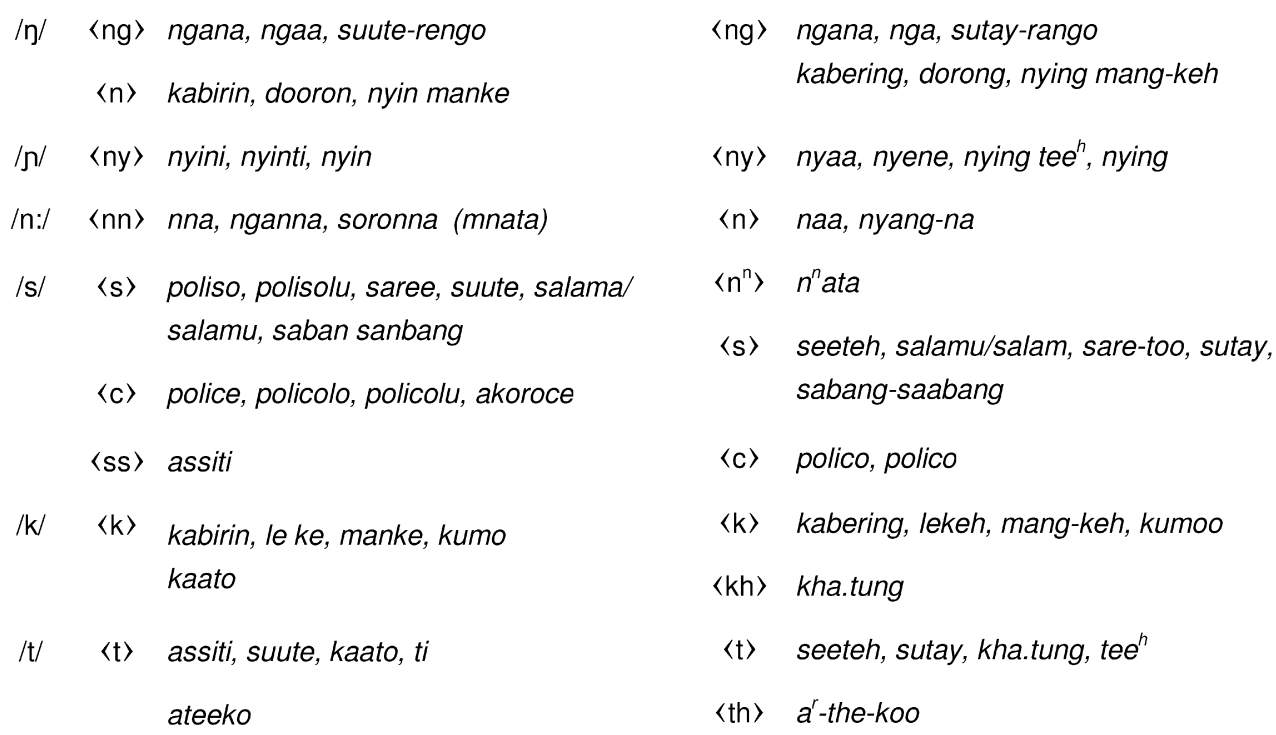


Representation of vowels

\begin{tabular}{|c|c|c|c|c|}
\hline \multirow[t]{3}{*}{ /i/ } & $\langle i\rangle$ & filita, assiti, kabirin, nyini & $\langle e e\rangle$ & fee lee ta, hanee, seeteh \\
\hline & $\langle i i\rangle$ & hanii & $\left\langle e e^{h}\right\rangle$ & $t e e^{h}$ \\
\hline & $\langle e\rangle$ & e la, ete & $\langle e\rangle$ & e la, nyene, kabering \\
\hline$/ 1 /$ & $\langle i\rangle$ & nyin, nyinti, kabirin, keedingo & $\langle i\rangle$ & nying, kabering \\
\hline \multirow[t]{2}{*}{ le/ } & $\langle e\rangle$ & aje, je, malekun, manke, suute, le ke & $\langle e h\rangle$ & $a^{r} j e h$, jeh, nteh, mang-keh \\
\hline & $\langle e e\rangle$ & saree, tarajee, jee & $\langle a y\rangle$ & sutay, alaykum \\
\hline $\mid \varepsilon /$ & $\langle e\rangle$ & suute-rengo, fengo & $\langle a\rangle$ & sutay-rango \\
\hline \multirow[t]{3}{*}{$\mid a /$} & $\langle a\rangle$ & faloo, filita, mnata, ngana & $\langle a\rangle$ & faloo, salamu, sabang, fanang \\
\hline & & & $\langle a h\rangle$ & fee lee tah \\
\hline & & & $\left\langle a^{r}\right\rangle$ & $a^{r} j e h, a^{r} y a a, a^{r}$ sutay, na', $a^{r} t e h$ \\
\hline /a:/ & $\langle a a\rangle$ & ngaa & $\langle a a\rangle$ & naa, nyaa, saabang, yaala, jumaa \\
\hline \multirow[t]{2}{*}{$10 /$} & $\langle 00\rangle$ & faloo, toobala, dooron, kaato & $\langle 00\rangle$ & faloo, too balaa, foo \\
\hline & $\langle 0\rangle$ & kaato, nko, fo & $\langle 0\rangle$ & dorong, nko \\
\hline$/ \mathrm{J} /$ & $\langle 0\rangle$ & dooron & $\langle 0\rangle$ & dorong \\
\hline \multirow[t]{2}{*}{$/ \mathrm{u} /$} & $\langle u\rangle$ & bulu, salamu, le mu, kumo, juma & $\langle u\rangle$ & buluu, sutay, salamu, le mu, kumoo, jumaa \\
\hline & $\langle u u\rangle$ & suute & $\langle u u\rangle$ & buluu \\
\hline
\end{tabular}

enforced in formal education, and not practically enregistered. ${ }^{4}$ Burama and Dembo both live in an environment that is poor in terms of access to and support for literacy production in Mandinka, or indeed any other local language. As a result, spelling in local languages remains an affair of creativity rather than convention (Kress, 2000). In other words, spellers are left in a normative vacuum, leaving them to spell without orthography. As Jaffe (2000:506) observes, 'it is not only important for [minority languages] to "have" an orthography but it is also critical for that orthography to have prescriptive power - to be standardised and authoritative [i.e., to be enregistered], like the orthographies of dominant languages'.

Both Burama and Dembo are surrounded by and exposed to a fair amount of written English in their private and public lives (e.g., through their children's education, in the linguistic landscape, on television, in newspapers). And English, as we know, is a language with a very strict orthographic regime, with very clear ideas of what is right and what is wrong. What we witness here is that the normative vacuum for writing in Mandinka is filled with norms that are available for writing in English, especially in the case of Dembo's respelling. We also witness that writing not reflecting this English orthographic influence very much is qualified as 'bad Mandinka', as writing with an accent, as a product that indexes a social identity of being uneducated. Non-formal education here is disqualified as not being education at all, both by my translators as well as by Burama himself (see Fragment 1, line 8).

\footnotetext{
${ }^{4}$ Although the discussion in this paper applies to the situation of The Gambia in 'Anglographic' (rather than Anglophone) West Africa, it may be presumed that a comparable situation exists with regard to mandingue and French in neighbouring countries such as Senegal, Mali and Guinea. However, the situation there is further complicated, especially in Guinea, by the practice of literacy in the N'ko script (Wyrod, 2008).
}

The difference between Burama and Dembo lies in their different 'learning histories', their educational biographies, and their differently valued routes to literacy. Burama has learned to write in Mandinka in adult education and Dembo has learned to write in English in primary and secondary school. Burama has not received any formal education and has thus not learned to write conventional English. As an educated man, Dembo never attended adult literacy classes and thus did not learn to write 'conventional' Mandinka. As a result of these different personal histories of learning, Burama's spelling reflects a mild influence of English spelling rules while Dembo's spelling draws extensively, almost exclusively, on typically English sound-letter correspondences.

Where Burama writes nna faloo filita 'my donkey got lost' in three words with careful detail for the geminated $/ \mathrm{n}: /$ in the possessive pronoun nna ('my') and presents the verbal construction filita (verb stem fili-, past aspect suffix -ta) in a single word, this is respelled as naa faloo fee lee tah without doubling the $\langle\mathrm{n}\rangle$ of $n n a /$ naa but reinterpreting the vowel here as a long vowel ( $\langle\mathrm{aa}\rangle$ instead of $\langle a\rangle$ ) and respelling filita without apparent morphological reason in three words as fee lee tah. Moreover, the two /i/ sounds in filita are in Dembo's version graphically represented with $\langle\mathrm{ee}\rangle$, fee lee tah. The same replacement of the $/ \mathrm{i} /=\langle\mathrm{i}\rangle$ rule into $/ \mathrm{i} /=\langle\mathrm{e}\rangle$ is applied in respelling nyini as nyene, and in changing kabirin into kabering. Another changed sound-letter correspondence rule adopted in Dembo's spelling is the introduction of two graphic signs, 〈ay〉 and $\langle e h\rangle$, for the representation of /e/. In both cases it is clear where Dembo's inspiration for these 'innovations' comes from, English orthography. ${ }^{5}$

\footnotetext{
${ }^{5}$ It should be noted here that $\langle\mathrm{eh}\rangle$ is, strictly speaking, not a grapheme in English orthography. It is, however, commonly used in the 'Anglographic' spelling of Gambian surnames as opposed to the use of 〈é> in the 'Francographic' spelling of the same surnames in the surrounding countries with a French colonial history. Compare, e.g., Janneh, Drammeh, Baldeh, Jaiteh with Diané, Dramé, Baldé, Diété.
} 
Burama spells the way he does, primarily because he has learnt how letter-combinations 'sound', whereas Dembo spells the way he does, primarily because he has learnt how sound-combinations 'look' (cf. Kress, 2000). The improvements Dembo deems necessary, are ironically not informed by his own experience with reading and writing Mandinka, but are drawn from his knowledge of English literacy conventions. Dembo rewrites Burama's texts the way he does, not because he knows the conventions of Mandinka literacy, but because he knows the conventions of English literacy. In the process of respelling the text, Dembo invents an ad hoc spelling for Mandinka that is far from a 'more correct' or 'better' spelling.

The linguistic resources used for writing Mandinka in The Gambia are located outside a self-referent tradition, located instead in the tradition of another language, English. This also applies to Burama's spelling, witness his occasional use of $\langle\mathrm{e}\rangle$ for $/ \mathrm{i} /$ (e la, ete), his neglect of the special Mandinka characters $\langle\mathrm{n}\rangle$ and $\langle\tilde{n}\rangle$ and the occasional use of $\langle\mathrm{c}\rangle$ for $/ \mathrm{s} /$ (polico, akoroce). Herein lays a powerful inequality that is inherent to small languages. Due to the much more conspicuous visual presence of English in various domains in Gambian society, and the absence of formal education in Mandinka in particular, ordinary persons spelling in Mandinka often resort to borrowing elements of other spelling systems that are more readily available to them, i.e., the conventions of written English.

This inequality is only indirectly related to the social and economic conditions of a literacy community. It is inherent in the very nature of small languages, and it has to do with what Spolsky (2009) calls the 'state of literacy', i.e., the infrastructure of linguistic, semiotic or symbolic resources there are for writing in 'a language' (e.g., a tradition of written text production, circulation and 'consumption', the currency of grammars and lexicons, a commonly recognised standard orthography). This is an inequality that has to do with the very size of the language.

Despite the inequality that is inherent to the medium of his literacy (roman-script Mandinka) and despite the non-standard, heterographic, grassroots character of his literacy (which is due to that inequality) and despite the reported negative comments by higher-literate persons, Burama's texts are by no means defunct in meaning or in the personal and professional contexts in which he produced them. This literacy, in his own words, has (had) great benefit to him and his family (see Fragment 4). It has given him an interesting job with a certain amount of (trans)national mobility, and has indirectly enabled him to feed his children and pay for their education. As is obvious from the series of texts presented in section 3 above (in particular Fragments 4 and 5), Burama is a proud and content man, not despite his literacy, but in great part, because of his literacy.

The implications of this small-scale ethnographic case of Mandinka spelling practices for postcolonial language policy and educational development should not be overestimated. If there is anything, however, that this case does not call for, then it is for standardising Mandinka spelling practices from above, or for the development and recognition of one orthography, i.e., one single set of norms for how to write right. In heterographic situations such as we witness here, there is not one, but several prescriptive regimes on how to write. In the absence of a single set of norms, individual and situational variation like in spoken language is not abnormal, but normal. It is only abnormalised in evaluative encounters such as the ones described above. In view of the creativity in grassroots spelling practices and the value this literacy has in the life of someone like Burama, heterography does not appear to be an exclusively bad thing. If Mandinka spelling is to standardise, then it would probably be most effective if it standardises from below. Standardisation in this context would best be left for people like Burama and Dembo to sort out in practice, in producing the texts they produce. Efforts to impose a particular spelling system on grassroots spellers would probably create more inequalities than it would empower spellers like Burama that are already subjected to negative peer-evaluation.

One lesson designers of adult literacy campaigns may want to draw from this study, is that we need to become aware of the potential for further disadvantaging adult literacy learners by proposing spelling conventions that depart too much from already existing spelling regimes. African local languages exist in a multilingual ecology and in contact with powerful languages such as English, French, Portuguese and Arabic (see also Stroud, 2003). Although these languages may provide awkward models for writing in local languages, they do provide readily available sets of rules that serve as actual resources for writing, and should therefore not be ignored in programmes of literacy and educational development.

Spelling in the local language, to conclude, is never just spelling in the local language, but is spelling in a complex multilingual ecology in which the postcolonial, world language assumes a powerful position. Spelling Mandinka in peri-urban Gambia is always spelling in the presence of English.

\section{References}

Agar, M., 1995. Ethnography. In: Verschueren, J., Östman, J.-O., Blommaert, J. (Eds.), Handbook of Pragmatics. John Benjamins, Amsterdam, pp. 583-590. Agha, A., 2005. Voice, footing, enregisterment. Journal of Linguistic Anthropology 15 (1), 38-59.

Basso, K.H, 1974. The ethnography of writing. In: Bauman, R., Sherzer, J. (Eds.), Explorations in the Ethnography of Speaking. Cambridge University Press, Cambridge, pp. 425-432.

Baynham, M., 2004. Ethnographies of literacy: introduction. Language and Education 18 (4), 285-290.

Blommaert, J., 2001. The Asmara Declaration as a sociolinguistic problem: reflections on scholarship and linguistic rights. Journal of Sociolinguistics 5 (1), 131142.

Blommaert, J., 2007. Sociolinguistic scales. Intercultural Pragmatics 4 (1), 1-19.

Blommaert, J., 2008. Grassroots Literacy: Writing, Identity and Voice in Central Africa. Routledge, London.

Brandt, D., 1997. The sponsors of literacy. College Composition and Communication 49 (2), 165-185.

Brock-Utne, B., Skattum, I., 2009. Languages and Education in Africa: A Comparative and Transdisciplinary Analysis. Symposium Books, Oxford.

Bunyi, G., 1999. Rethinking the place of African indigenous languages in African education. International Journal of Educational Development 19 (4-5), 337350.

Clastres, P., 1998 [1972]. In: Auster, P. (Ed.), Chronicle of the Guayaki Indians. Zone Books, New York

Clifford, J., 1997. Routes: Travel and Translation in the Late Twentieth Century. Harvard University Press, Cambridge.

Colley, E.S.Y., 1995a. Mandinka-English Dictionary. Peace Corps The Gambia, Banjul. Colley, E.S.Y., 1995b. Mandinka Grammar Manual. Peace Corps The Gambia, Banjul. de Swaan, A., 2001. Words of the World: The Global Language System. Polity, Cambridge.

Dong, J., 2010. The enregisterment of Putonghua in practice. Language \& Communication 30 (4), 265-275.

DoSE, 2004. Education Policy 2004-2015. Department of State for Education, Banjul.

Ethnologue, 2009. In: Lewis, M.P. (Ed.), Ethnologue: Languages of the World, 16th edition. SIL International, online version: www.ethnologue.com, Dallas.

Fabian, J., 1990. History from Below: The 'Vocabulary of Elisabethville' by André Yav: Text, Translations and Interpretive Essay. John Benjamins, Amsterdam.

Fabian, J., 1992. Keep listening: ethnography and reading. In: Boyarin, J. (Ed.), The Ethnography of Reading. University of California Press, Berkeley, pp. 80-97.

Fabian, J., 2001. Anthropology with an Attitude: Critical Essays. Stanford University Press, Stanford.

Faye, J.C., Sillah, M.A., 1956. The Orthography of Gambian Languages: Mandinka and Wolof. Government Printer, Bathurst.

Geertz, C., 1973. Thick description: toward an interpretive theory of culture. In: The Interpretation of Cultures: Selected Essays, Basic Books, New York, pp. 3-30.

Geertz, C., 1998. Deep hanging out. The New York Review of Books 45 (16), 22 October.

Hymes, D.H., 1967. Models of the interaction of language and social setting. Journal of Social Issues 2, 8-28.

Jaffe, A., 2000. Introduction: non-standard orthography and non-standard speech. Journal of Sociolinguistics 4 (4), 497-513.

Jaffe, A., 2009. Entextualization, mediatization and authentication: orthographic choice in media transcripts. Text \& Talk 29 (5), 571-594. 
Jørgensen, J.N., 2008. Polylingual languaging around and among children and adolescents. International Journal of Multilingualism 5 (3), 161-176.

Juffermans, K., 2009. How to write if you cannot write: collaborative literacy in a Gambian village. In: van de Craats, I., Kurvers, J. (Eds.), Low-Educated Adult Second Language and Literacy Acquisition. LOT Netherlands Graduate School of Linguistics, Utrecht, pp. 223-234.

Juffermans, K., 2010. Local Languaging: Literacy Products and Practices in Gambian Society, Language and Culture Studies. Tilburg University.

Juffermans, K., McGlynn, C., 2009. A sociolinguistic profile of The Gambia. Sociolinguistic Studies 3 (3), 129-155.

Kress, G., 2000. Early Spelling: Between Convention and Creativity. Routledge, London.

Kroon, S., Sturm, J., 2000. Comparative case study research in education: methodological issues in an empirical-interpretive perspective. Zeitschrift für Erziehungswissenschaft 3 (4), 559-576.

Lillis, T., 2008. Ethnography as method, methodology, and 'deep theorizing': closing the gap between text and context in academic writing research. Written Communication 25 (3), 353-388.

Lück, M., Henderson, L., 1993. Gambian Mandinka: Learning Manual for EnglishSpeakers. WEC International, Banjul.

Lüpke, F., 2011. Orthography development. In: Austin, P., Sallabank, J. (Eds.), The Cambridge Handbook of Endangered Languages. Cambridge University Press, Cambridge.

Mbodj-Pouye, A., 2008. Pages choisies: Ethnographie du cahier personnel d'un agriculteur malien. Sociologie et Sociétés 40 (2), 87-108.

Mbodj-Pouye, A., 2009. Tenir un cahier dans la région cotonnière du Mali. Support d'écriture et rapport à soi. Annales. Histoire, Sciences sociales 64 (4), 855-886.

McGlynn, C., Martin, P., 2009. 'No vernacular': tensions in language choice in a sexual health lesson in The Gambia. International Journal of Bilingual Education and Bilingualism 12 (2), 137-155.

Phillipson, R., 1992. Linguistic Imperialism. Oxford University Press, Oxford.

Rampton, B., 2000. Speech community, Working Papers in Urban Language and Literacies, London.

Rogers, A., 2004. Looking again at non-formal and informal education: towards a new paradigm, The Encyclopaedia of Informal Education. www.infed.org, London.

Sarangi, S., 2007. Editorial: The anatomy of interpretation: coming to terms with the analyst's paradox in professional discourse studies. Text \& Talk 27 (5-6), 567584.
Sebba, M., 2000. Orthography and ideology: issues in Sranan spelling. Linguistics 38 (5), 925-948.

Sebba, M., 2009. Sociolinguistic approaches to writing systems research. Writing Systems Research 1 (1), 35-49.

Sidibe, B.K., 1979. A New Orthography of Gambian Mandinka. National Literacy Advisory Committee, Banjul.

Skutnabb-Kangas, T., Phillipson, R., Kontra, M., 2001. Reflections on scholarship and linguistic rights: a rejoinder to Jan Blommaert. Journal of Sociolinguistics 5 (1), $143-154$.

Spolsky, B., 2009. Prolegomena to a sociolinguistic theory of public signage. In: Shohamy, E., Gorter, D. (Eds.), Linguistic Landscape: Expanding the Scenery. Routledge, London, pp. 25-39.

Street, B.V., 2000. Literacy events and literacy practices: theory and practice in new literacy studies. In: Martin-Jones, M., Jones, K.E. (Eds.), Multilingual Literacies: Reading and Writing in Different Worlds. John Benjamins, Amsterdam, pp. 1729.

Stroud, C., 2003. Postmodernist perspectives on local languages: African mothertongue education in times of globalisation. International Journal of Bilingual Education and Bilingualism 6 (1), 17-36.

Szwed, J.F., 1981. The ethnography of literacy. In: Farr Whiteman, M. (Ed.),Writing: The Nature, Development, and Teaching of Written Communication, vol. 1: Variation in Writing: Functional and Linguistics-Cultural Differences. Lawrence Erlbaum, Hillsdale, pp. 13-23.

Van Camp, K., Juffermans, K., 2010. Postcolonial ideologies of language in education: voices from below on English and local language(s) in The Gambia. In: Cuvelier, P., du Plessis, T., Meeuwis, M., Vandekerckhove, R., Webb, V. (Eds.), Multilingualism from Below. Van Schaik, Pretoria.

International, W.E.C., 2002. Mandinka Learning Manual: Short Version. WEC International, Banjul.

WEC International, 2010 [undated]. How to write Mandinka: Instructions for Those Who are Used to Write in English. WEC International, Mandinka Literacy Department, www.mandinka.org, Banjul.

Williams, E., 2006. Bridges and Barriers: Language in African Education and Development. St Jerome, Manchester.

Wogan, P., 2004. Deep hanging out: reflections on fieldwork and multisited Andean ethnography. Identities: Global Studies in Culture and Power 11, 129-139.

Wyrod, C., 2008. A social orthography of identity: the N'ko literacy movement in West Africa. International Journal of the Sociology of Language 192, 27-44. 